\title{
Correction to: Assessing Short-Term and Long-Term Economic and Environmental Effects of the COVID-19 Crisis in France
}

\author{
Paul Malliet ${ }^{1}$ (D) $\cdot$ Frédéric Reynès $^{1,2,3} \cdot$ Gissela Landa $^{1} \cdot$ Meriem Hamdi-Cherif $^{1}$. \\ Aurélien Saussay ${ }^{1,4}$
}

Published online: 1 October 2020

(c) Springer Nature B.V. 2020

\section{Correction to: Environmental and Resource Economics (2020) 76:867-883 https://doi.org/10.1007/s10640-020-00488-z}

The article was published with a typographical error in one reference. The author group and the editors ask that reference,

Aubert, D., Chiroleau-Assouline, M. (2019) Environmental tax reform and income distribution with imperfect heterogeneous labour markets. European Economic Review 116: 60-82.

be instead referenced as,

Aubert, D., Chiroleu-Assouline, M. (2019) Environmental tax reform and income distribution with imperfect heterogeneous labour markets. European Economic Review 116: 60-82.

This correction stands to correct the original article.

Publisher's Note Springer Nature remains neutral with regard to jurisdictional claims in published maps and institutional affiliations.

The original article can be found online at https://doi.org/10.1007/s10640-020-00488-z.

\section{Paul Malliet}

paul.malliet@sciencespo.fr

1 OFCE - French Economic Observatory, Paris, France

2 NEO - Netherlands Economic Observatory, Rotterdam, The Netherlands

3 TNO - Netherlands Organization for Applied Scientifc Research, The Hague, The Netherlands

4 LSE - London School of Economics, London, UK 